\title{
ARTISTIC AESTHETIC FUNCTION OF MONOLOGUES
}

\author{
Hotamjon Khamroevich Abdullayev
}

Student, Karakalpak State University, Nukus, Uzbekistan

\section{ABSTRACT}

This article is based on the novel "Humoyun and Akbar" by Uzbek writer Pirimkul Kadyrov. The article analyzes the artistic and aesthetic function of monologues in the novel.

KEYWORDS: - Novel, monologue, character, monologue-memory, monologue-reflection, monologuediscussion, external monologue, internal monologue.

\section{INTRODUCTION}

In a work of art, the psyche of character unites the boundaries of artistic consciousness. In particular, it is impossible to gain the trust and attention of the reader without a picture of the connection between history and the present and the future. Creating the character of historical figures, especially in historical novels, requires special skill from the writer. After the independence of our people, our literature embodied the traditional means of psychological imagery, and now more attention is paid to the study of the inner world of the hero in relation to the social environment in which he lived. The spiritual needs of today's man (reader), who takes a fresh look at nature and society, the past, cannot be satisfied by works that contain only the details of events. Because today's man is interested not only in the external activities of the hero, but also in knowing and understanding his inner spiritual world.

\section{THE MAIN FINDINGS AND RESULTS}

Creating the character of historical figures is the main task before every writer who creates a historical novel. As the literary critic M. Kushjanov said: "Artistic character is the direction of the will of a person who has acquired a social meaning in a particular social context, including individual traits, and the artistic expression of that direction in the work. Only the will of the individual, formed on the basis of social conditions, provides the artistic and ideological basis of the character in the play" [1.5].

In this article, we will focus on the monologue and its types from the tools of psychological analysis.

One of the most effective ways to skillfully express the spirit of the protagonist (especially in historical novels) is to use monologues correctly and appropriately. 
CURRENT RESEARCH JOURNAL OF PHILOLOGICAL SCIENCES 2(7): 16-19,

May 2021 DOI: https://doi.org/10.37547/philological-crjps-02-07-05

ISSN 2767-3758

(C)2021 Master Journals

\section{Crossref do) 8 Google}

Accepted24thJuly, 2021 \& Published 29thJuly, 2021

His soul is troubled, as Jalaliddin Rumi put it: "Your body is a horse; your soul is its rider. Know that horse food is not food for the rider". In the past, Akbar used to take care of his body more, but now he knows that he has taken care of the horse and left the rider hungry" [3. 463].

This internal monologue is a monologue. The ministers and sheikhs around him considered Akbar a "Mahdi", "genius" a "mujtahid", and even convinced him that he was a prophet in the eyes of God, not an ordinary human being. Akbar now believes in this and waits for revelation from Allah. This was Akbar's inner and spiritual weakness. Writer Jalaliddin Rumi's wise words "Your body is your horse, your soul is his rider" from Akbar's language ensures the formation of the hero's character and his aspiration to spiritual heights. It is by quoting this wisdom that the reader is guided to pure human virtues and feels in his heart that the soul is superior to all things.

The above example shows that in an internal monologue, the conflict of ideas prevails over the external monologue. Literary critics N.Khotamov and B.Sarimsakov argue that monologues and internal monologues are not the same phenomenon, they have their own peculiarities. .Atimov's article "The program is renewed".

In P. Kadyrov's novel, which is the object of this research, there are different types of monologues: monologue-memory, monologuereflection, and monologue-discussion. These types of monologues clarify the dialectic of the protagonist's soul, the dependence of his psyche on the environment.

"It simply came to our notice then. "Keep calm and forget the difficult things that Mirza Humayun has assigned you. Each of these princes looks like a naked sword. If you make a mistake, cut off your head! " Hazrat Nizamiddin thought it was a dry panic: "Now, with the power of this golden harvest, I will subdue even the most violent princes!" he says. Nizam warns him: "Don't go too big, it's just a waste of money. After all, the gold was cut from the share of farmers and artisans. How many tyrants did the oppressors commit before they came to collect the coins? Remember the injustice you did when you were a poor oarsman! [3. 99].

In this monologue, the author's speech and Nizam's speech are synchronized, adding more emotion and attracting the reader. At the same time, in the life of the reader there is an idea to discuss the state of mind of the Charter, or the reader tries to reveal the state of mind by putting himself in the place of the Charter. This is a testament to the writer's high level of skill and increases the readability of the book. Such monologues immerse the reader in the world of the work. As the reader listens to the inner speech of the protagonist, he joins the image and does not fall into a trance, and in his heart there is a feeling of sympathy for the ordinary sailor Nizam.

The internal monologue above is a description of the post-accession status of the Statute. It seems very unbelievable that King Humayun, an ordinary sailor, brought Nizam to the throne only because he was his savior, or that this episode was given. Because after reading this episode, the reader asks himself the question of how the king of such a great nation as Humayun handed over his throne to a simple, inexperienced young man. Everyone understands that this is not crazy. But that is exactly what happened. M.Nuriddinov in his pamphlet "Baburi dynasty" wrote: will be. The waterman's name was Nizam. Humayun acknowledges his debt to him and promises to give you the throne of the semi-kingdom if we can easily reach Agra".

Thanks to the generosity of King Humayun, Nizam Suvchi will now be the king of someone. As mentioned above, King Humayun presented his throne to his savior Nizam for half a day. No 
CURRENT RESEARCH JOURNAL OF PHILOLOGICAL SCIENCES 2(7): 16-19,

May 2021 DOI: https://doi.org/10.37547/philological-crjps-02-07-05

ISSN 2767-3758

(C)2021 Master Journals

\section{Crossref do) 8 Google}

Accepted24thJuly, 2021 \& Published 29thJuly, 2021

matter how historical or artistic the story is, P. Kadyrov tried to reveal the feelings of the people by bringing the Charter to the throne. Now who will deliver this letter to Anvar? Hazrat Nizamiddin summoned the treasurer and prepared two wallets full of gold. This money can be hired from savvy runners. But the secret of Hamida Bonu cannot be told to everyone. Must be a very reliable person. The most trusted man in the palace for Nizam was Humayun. "Sir, advise Mirza Humayun", said Nizam. But shouldn't Hazrat Nizamiddin carry out some of his subtle intentions without telling Humayun everything? What if he solved a problem on his own?" [3.102]

It is a monologue-discussion that assesses a friend's attitude and loyalty to a friend under certain conditions. It's as if the author is extracting wisdom from the proverb "Give your friend a status" through this monologue. Through this monologue, one tries to reveal the hidden, unknown, and self-evident aspects of the human heart. In the monologue, the writer searches for and selects words that fit the character's mood. $\mathrm{He}$ is especially good at using the monologue method of asking questions and discussing certain issues.

So, the inner monologue is a way to convey to the reader the difficult state of mind of the protagonists, their hidden, unexplained pain.

"It was as if the rivers overflowing on three sides were trapping him on the other side", he said. 0 my god! Why did he go into the river with his foot? When his father settled here, the air was dry, there was little water in the rivers, and there was no dangerous beast like Sherkhan in this area" [3. 64-65]

This inner monologue is given after the episode of Humayun's dream and seems to predict his defeat in a battle with the enemy. Indeed, in the battle with Sherkhan, Humayun is defeated, and the fact that the rivers overflowing from three sides seem to trap him in the enemy creates a depressing mood in the hero's psyche. By giving this monologue after Humayun's dream, the writer explains in his own language that the protagonist did something wrong. In addition, Sherkhan warns the reader in advance of a terrible event in the battle with the army. This leads the reader to delve deeper into the events of the work. In this way, the reader's interest in the work increases.

\section{Conclusion}

The writer P. Kadyrov is also a talented artist with a unique artistic experience. The art of revealing the psychology of real historical figures in historical-biographical novels through internal monologues is a testament to the perfect and creative study of experiences in fiction.

However, this view does not mean that $P$. Kadyrov's method of using internal monologues in the psychological direction was formed under the influence of the work of this or that writer. Because the ability of a person (writer-creator) to think universally depends on their contemporaries and the closeness of their worldviews. But the writers' style of character creation is different. A.Zayniddinova notes the originality of P. Kadyrov's "Starry Nights" and 0. Yakubov"s "Ulugbek's Treasure" novels: goes through a series of openings. In Kadyrov's work, the formation of Babur's worldview and character is shown throughout the work" [2.70].

It turns out that, as noted above, P.Kadyrov does not create an image of a particular historical situation or a complete picture of the hero. Perhaps, at the same time, the events of the work in the process of dialectical development illuminate both the image of the situation and the image of the protagonist's inner experiences. This leads to the emergence of internal monologues, in which the protagonist and the reader have an idea, and try to come out of 
CURRENT RESEARCH JOURNAL OF PHILOLOGICAL SCIENCES 2(7): 16-19,

May 2021 DOI: https://doi.org/10.37547/philological-crjps-02-07-05

ISSN 2767-3758

(C)2021 Master Journals

Crossref dof 81 Google

Accepted24thJuly, 2021 \& Published 29thJuly, 2021

unexpected situations together with the protagonist.

\section{REFERENCES}

1. Kushjanov M. (1965) Oybek's Skill. Tashkent.

2. Zayniddinova A. (1992) "Historical and artistic truth". - Tashkent.

3. Qodirov P. (1997) "Humayun and Akbar". Tashkent.

4. Khudoyorovich, K. K., Rasuljanovna, I. N., Khalmuratovna, R. Z., \& Eshkobilovna, K. D. (2020). The Issues of Word Choice in Fiction Translation. International Journal of Psychosocial Rehabilitation, 24(04).

5. Rasuljanovna, I. N. (2019). The phenomenon of lacunarity as the linguacultural issue. Prospects of world science-2019, 226. 